\title{
Pyrogenic carbon distribution in mineral topsoils of the northeastern United
}

States

Verena Jauss ${ }^{1}$, Patrick J. Sullivan ${ }^{2}$, Jonathan Sanderman ${ }^{3}$, David B. Smith ${ }^{4}$, Johannes Lehmann ${ }^{1,5 *}$

${ }^{1}$ Soil and Crop Sciences, Cornell University, Ithaca, NY 14853, USA

${ }^{2}$ Department of Natural Resources, Cornell University, Ithaca, NY 14853, USA

${ }^{3}$ CSIRO Land and Water, Glen Osmond, Australia

${ }^{4}$ U.S. Geological Survey, Denver, CO 80225, USA

${ }^{5}$ Atkinson Center for a Sustainable Future, Cornell University, Ithaca, NY 14853, USA

* Corresponding author. Address: Cornell University, 909 Bradfield Hall. Ithaca, NY 14853. Phone: +1 607254 1236. E-mail: CL273@cornell.edu 


\section{Abstract}

Due to its slow turnover rates in soil, pyrogenic carbon $(\mathrm{PyC})$ is considered an important $\mathrm{C}$ pool and relevant to climate change processes. Therefore, the amounts of soil PyC were compared to environmental covariates over an area of $327,757 \mathrm{~km}^{2}$ in the north-eastern United States in order to understand the controls on PyC distribution over large areas. Topsoil (defined as the soil A horizon, after removal of any organic horizons) samples were collected at 165 field sites in a generalised random tessellation stratified design that corresponded to approximately 1 site per $1,600 \mathrm{~km}^{2}$ and PyC was estimated from diffuse reflectance mid-infrared spectroscopy measurements using a partial least-squares regression analysis in conjunction with a large database of PyC measurements based on a solid-state ${ }^{13} \mathrm{C}$ nuclear magnetic resonance spectroscopy technique. Three spatial models were applied to the data in order to relate critical environmental covariates to the changes in spatial density of PyC over the landscape. Regional mean density estimates of PyC were $11.0 \mathrm{~g} \mathrm{~kg}^{-1}\left(0.84 \mathrm{Gg} \mathrm{km}^{-2}\right)$ for Ordinary Kriging, $25.8 \mathrm{~g} \mathrm{~kg}^{-1}\left(12.2 \mathrm{Gg} \mathrm{km}^{-2}\right)$ for Multivariate Linear Regression, and $26.1 \mathrm{~g} \mathrm{~kg}^{-1}\left(12.4 \mathrm{Gg} \mathrm{km}^{-2}\right)$ for Bayesian Regression Kriging. Akaike Information Criterion (AIC) indicated that the Multivariate Linear Regression model performed best ( $\mathrm{AIC}=842.6 ; \mathrm{n}=165)$ compared to Ordinary Kriging $(\mathrm{AIC}=982.4)$ and Bayesian Regression Kriging $(\mathrm{AIC}=979.2)$. Soil PyC concentrations correlated well with total soil sulphur $(P<0.001 ; n=165)$, plant tissue lignin $(P=0.003)$, and drainage class $(P=0.008)$. This suggests the opportunity of including related environmental parameters in the spatial assessment of $\mathrm{PyC}$ in soils. Better estimates of the contribution of PyC to the global carbon cycle will thus also require more accurate assessments of these covariates. 
Keywords: Pyrogenic carbon; climate change; fire; soil development; soil organic matter; Bayesian regression kriging 


\section{Introduction}

Climate change has triggered an increasing interest in biogeochemical carbon (C) cycling and the question of how global change affects biotic processes. Recent studies suggest that the biosphere currently acts as a C sink (Schimel et al., 2001; Pan et al., 2011). However, the sink strength may decrease over time, turning the biosphere into a C source (IPCC 2014). The largest uncertainty in predicting C turnover in the terrestrial biosphere is the soil (Tian et al. 2015), which stores at least three times as much $\mathrm{C}$ as either the atmosphere or terrestrial vegetation (Friedlingstein et al., 2006; Schmidt et al., 2011). Hence, soil organic C (SOC) is the main component of the terrestrial $\mathrm{C}$ cycle and accounts for annual carbon dioxide emissions that are an order of magnitude higher than all anthropogenic carbon dioxide emissions taken together (IPCC, 2014). Decomposition of SOC by microorganisms is likely to intensify through global warming, augmenting the release of carbon dioxide into the atmosphere (Davidson and Janssens, 2006). If, however, a larger fraction of SOC were to demonstrate slower decomposition rates than currently assumed, the soil respiration-warming feedback may have been over estimated and current models of global climate change would need to be revised (Lehmann et al., 2008).

Slow-cycling SOC is either protected by minerals (organo-mineral interactions, adsorbed OC, contained in aggregates) or chemically altered with a highly aromatic structure and few oxygenated functional groups (pyrogenic carbon), which makes it a less preferred energy source for microbial decay (Preston and Schmidt, 2006; Schmidt et al., 2011).

While the formation of stabilized plant residues may take a multitude of pathways (Kleber et al., 2007), pyrogenic carbon (PyC) is produced by partial 
combustion of plant material and is a major component of a continuum from charcoal to soot to graphite (Kuhlbusch, 1998; Schmidt and Noack, 2000; Preston and Schmidt, 2006). Although PyC can be degraded both chemically and biologically, it decomposes at a slow rate, with mean residence time in soils estimated from decades to millennia (Lehmann et al., 2015; Wang et al., 2015). Therefore, it mineralizes significantly slower than other litter input (Ansley et al., 2006), providing a greater potential for $\mathrm{PyC}$ to act as a significant $\mathrm{C}$ sink from the more rapid bioatmospheric $\mathrm{C}$ cycle to the slower (long term) geological $\mathrm{C}$ cycle (Forbes et al., 2006; Ohlson and Tryterud, 2000). Skjemstad et al. (2002) found that PyC can constitute a significant proportion of SOC with up to $35 \%$ in several long-term experiments in the United States. Despite these findings of the importance of PyC, most recent C-related studies focus merely on non-PyC components and, therefore, neglect to address the long-term environmental significance of PyC stock changes in the global $\mathrm{C}$ cycle. Additionally, most available PyC data are collected as point data without attempting to correlate these measurements to other environmental properties of the surrounding landscape (Murage et al., 2007). Transformational processes and products, initially driven by climate and geomorphology, define the landscape's natural potential which influences ecosystem characteristics, for instance the capacity to act as a C sink or source (Blümel, 2009). In order to quantify this potential and upscale point measurements to the landscape scale, accurate information about the spatial distribution of $\mathrm{PyC}$ in soils of different ecosystems and the relationship to other environmental parameters are important to support projections of future climate change (Lehmann et al., 2008). Consequently, so as to better understand the importance of PyC in the global $\mathrm{C}$ cycle, an understanding of the spatial distribution of PyC is required (Bird et al., 2015; Reisser et al., 2016; 
Santin et al., 2016). To date, studies assessing spatial patterns of PyC in soils over large areas have been scarce, may combine PyC estimates from many different analyses protocols (Reisser et al., 2016) and often only focus on soot-derived PyC (Shaoda et al., 2011; Paroissien et al., 2012).

Therefore, the aim of this study was to assess the amount of PyC in topsoils of the northeastern United States, to determine the importance of related environmental parameters in the overall distribution of $\mathrm{PyC}$ on a landscape scale and to evaluate the performance of different spatial models in predicting PyC distribution over large areas. Specifically, the suitability of Ordinary Kriging, Multivariate Linear Regression and Bayesian Regression Kriging was examined with the goal to obtain the best model to depict and quantify spatial patterns of PyC distribution in the landscape.

\section{Materials and Methods}

\subsection{Study region}

The sample sites are located in the northeastern United States, a part of the humid temperate zone, which globally covers $9.7 \%$ of the global terrestrial landmass. Mean annual temperature ranges from $8^{\circ} \mathrm{C}$ to $12^{\circ} \mathrm{C}$ and mean annual precipitation from $600 \mathrm{~mm}$ to $1000 \mathrm{~mm}$. Rainfall is broadly distributed throughout the year. Temperate broadleaf and mixed forests comprise the predominant natural vegetation type. The organic layer consists of slightly acidic to slightly alkaline mull, which is rich in nutrients and carbon compared to the underlying mineral horizons. Both climate and vegetation control soil formation in this ecoregion and primarily lead to the development of dystric to eutric Cambisols, Luvisols and Podzoluvisols (Goudie, 2001; Woodward, 2003). 


\subsection{Sample collection and analysis}

A composite of the soil A horizon (ca. $1 \mathrm{~kg}$ of the uppermost mineral soil, up to $0.1 \mathrm{~m}$ depth for the study region, after removal of the organic horizon if present) was collected using either soil profiles or augers at 165 sample sites in the six New England states and New York State (Supplementary Fig. S1) as part of the U.S. Geological Survey's North American Soil Geochemical Landscapes Project (Smith et al., 2012, 2013, 2014). No additional field information was collected at the time of soil sampling. Additional soil and site information was obtained from other databases (Supplementary Tables S1 and S2). Field sites were selected using a generalised random tessellation stratified design that corresponded to approximately 1 site per $1,600 \mathrm{~km}^{2}$ (Stevens and Olsen, 2004). This is a low sampling intensity compared to the processes that are likely responsible for soil PyC distribution, but is a typical sampling density available for large-scale spatial analyses of soils (e.g., for Africa 1 site per $1122 \mathrm{~km}^{2}$, Hengl et al., 2016; for Europe 1 site per $199 \mathrm{~km}^{2}$, Ballabio et al., 2016). Our analyses therefore reflect assessments of PyC spatial distribution, the ability to understand its drivers and the opportunities to improve spatial interpolation using co-variates for a data density typical of soil inventories.

The samples were air-dried, disaggregated and sieved to $<2 \mathrm{~mm}$. This material was then finely ground prior to chemical analysis (Smith et al., 2013). Adapting the method of Briggs (2002), a USGS contract laboratory determined total sulphur (S) concentration by a near-total four-acid (hydrochloric, nitric, hydrofluoric, and perchloric) digestion at a temperature between 125 and $150^{\circ} \mathrm{C}$ followed by inductively coupled plasma-atomic emission spectrometry (ICP-OES Optima 5300/7300, Perkin Elmer Inc., Waltham, MA, USA). 
A chemometric prediction method was used to estimate PyC contents whereby mid-infrared (MIR) spectra were correlated with large dataset of labproduced PyC quantification from soils in Australia (Baldock et al., 2013a, b). Finely ground and homogenized samples (Retsch Ball Mill, MM400, Haan, Germany) were analyzed by diffuse reflectance MIR spectroscopy using the identical spectroscope for the Australian calibration set and the US soils presented in this study. Spectra between 8000 and $400 \mathrm{~cm}^{-1}$ were recorded with a Nicolet $6700 \mathrm{FTIR}$ spectrometer (Thermo Fisher Scientific Inc., Waltham, MA, USA) equipped with a $\mathrm{KBr}$ beamsplitter, a DTGS detector and an AutoDiff-Automated diffuse reflectance accessory (Pike Technologies, Madison, WI, USA). Subsequent partial least squares (PLS) regression analysis of $\mathrm{PyC}$ was carried out with the Unscrambler 10.2 software package (CAMO software AS, Oslo, Norway). In this, a standard set of 312 Australian soils, previously analyzed for PyC using HF treatment followed by solidstate ${ }^{13} \mathrm{C}$ nuclear magnetic resonance (NMR) spectroscopy, served as PLS calibration data. Test set validation indicated a root mean square error of $0.324 \mathrm{mg} \mathrm{C}$ $\mathrm{g}^{-1}$ with an R-square of 0.85 (Baldock et al., 2013b).

An outlier ratio based on Hotelling's T-squared distribution and an inlier ratio based on the Mahalanobis distance derived using the Unscrambler 10.2 software (CAMO Software AS, Oslo, Norway) were applied to determine how closely our field site PyC data in the US north-east aligned with the range of data used in the PLS calibration data set from Australia. Under the similarity assumptions associated with the PLS model fit to the calibration data, no more than about $5 \%$ of the calibration samples should be expected to lie beyond the threshold for each metric (i.e. having a ratio $>1$ ). For the soils being predicted in this study, approximately $58 \%$ were found to be beyond the Hotelling's critical value for the outlier ratio and $8 \%$ beyond the 
Mahalanobis critical value for the inlier ratio (Fig. 1), thus providing a measure of distance between our data and the data used for the calibration. Consequently, $58 \%$ of our data lie beyond the current predictive range of this model and prudence should be exercised in interpreting the results. One possibility would be to downweight the elements of the data that are statistically beyond the base calibration data set. This might be appropriate if the variables used for the prediction were scattered more or less randomly outside of its range. However, this is a spatial prediction, so sites with characteristics that lie beyond those of the calibration data are in fact aggregated in specific regions. Thus down-weighting or eliminating these data would leave gaps in the prediction. Even so the predicted means are not likely to change from those presented here, although their variance increases. Consequently, for our purposes of relating PyC contents to each other and to site variables, we assume that the established linear relationship is appropriate.

\subsection{Statistical analysis}

Additional environmental data were assembled to further characterize the region, to inform the modelling approach for better spatial prediction of PyC and to identify possible drivers of regional distribution of PyC in soil, including parameters possibly responsible for PyC input (e.g., biomass, plant tissue lignin, soil S, fire intensity and frequency) and disappearance (e.g., soil drainage, slope gradient, aspect, mean annual temperature, mean annual precipitation, combined silt and clay content) (all parameters and their sources listed in Supplementary Table S1).

Although additional correlations of PyC can in some cases be found (Jauss et al., 2015), this study focused on those predictors for which a functional relationship can be hypothesized and data be accessed. Amounts of PyC may be positively 
correlated to SOC (Glaser and Amelung, 2003; Jauss et al., 2015), as PyC is part of the SOC pool. However, physical drivers that lead to accumulation of PyC and SOC in soils are for the most part unrelated. Therefore, any correlation between PyC and $\mathrm{SOC}$ is spurious and $\mathrm{PyC}$ concentrations in the soil are highly variable with regard to total soil C contents (Janik et al., 2007). Consequently, we did not include SOC as a potential predictor variable.

Properties for the topsoil $(0-0.1 \mathrm{~m})$ of the entire region such as soil drainage and bulk density were derived from the STATSGO database (Soil Survey Staff, Natural Resources Conservation Service, United States Department of Agriculture, 2006). Data for the existing vegetation were obtained from The National Map LANDFIRE (2006) (for complete list of sources, see Supplementary Table S1). For neither database were uncertainty estimates available. In addition to obtaining data layers for the entire region, specific values for the study sites were extracted using the Intersect Point Tool in Hawth's Tools (Beyer, 2004) in ArcGIS 9.3 (ESRI, 2009). The data for vegetation taken from The National Map LANDFIRE (2006) was not used directly. Instead, through a literature review continuous Klason lignin values were obtained, which are derived from ground biomass constituent insoluble in $72 \%$ sulphuric acid (Klason, 1908), and thus these lignin values were assigned to the categorical Vegetation Group values (Pickering, 2008; Rowell, 2005; Corker and Boyer, 1975; Pettersen, 1984; Ostrofsky, 1997; Wenzl, 1970; Brauns and Brauns, 1960; Park and Kim, 2012; Wayne Cook and Harris, 1952; Wilson, 1985; Bray et al., 2012; Sharpe et al., 1980; Severson and Ursek, 1988; Lamoot, 2004; Butkuté et al., 2013; Conn, 1994; Wainio and Forbes, 1941; Smith and Kadlec, 1984; Laursen, 2004; Abideen et al., 2011; van Niekerk et al., 2004; Sultan et al., 2009; Fukushima and Hatfield, 2004). This data was used for the linear regression analysis. For the 
final map predictions, lignin values were determined for all Vegetation Group values in the raster layer, including those not represented at the sample locations, and the entire dataset was used.

A Bayesian hierarchical model was used to explore three alternative methods for predicting the landscape-scale distribution of PyC in the soil, and implemented on a common modelling platform described below, rather than using commercially available statistical software. The three alternative approaches were: 1 . Ordinary Kriging; 2. Multivariate Linear Regression with independent error; and 3. Bayesian Regression Kriging with a linear model and autocorrelated error. The three alternative approaches can be represented by a single model formulation:

$$
\mathbf{Y}=\mathbf{X}^{\prime} \boldsymbol{\beta}+\boldsymbol{\varepsilon} \quad \boldsymbol{\varepsilon} \sim \operatorname{MVN}(\mathbf{0}, \boldsymbol{\Sigma})
$$

where $Y$ represents the vector of observations on $\mathrm{PyC}, \mathrm{X}$ the predictor variables, $\beta$ is the vector of associated coefficients, and $\varepsilon$ is the vector of possibly spatially autocorrelated errors following a multivariate normal probability distribution with a mean vector of zeros 0 and variance-covariance matrix $\Sigma$ which itself is a function of the pairwise distances between points using a spherical covariogram model and parameterized with the parameters $\Theta$ representing the range, partial sill and tau (global precision). It is common in the classical geostatistical literature to find the variogram defined in terms of the sill (global variation), nugget (small scale variation) and range (distance over which spatial correlation is occurring). Here we define the variogram in more modern terms of the tau (precision that is the square root of the inverse of the global variance), the partial sill (sill-nugget) and the range. The latter three are used to facilitate optimal estimation. Precision, for example, is often a more stable estimator than variance. Regression parameter estimates were considered significant at $\mathrm{P}<0.05$. 
Considering the model more broadly, three different variations can be made out in our model, depending on data input to Eq. 1 . When $\beta$ is simply a vector of ones, the model represents the ordinary kriging model. The multivariate linear model results when $\Sigma$ is a diagonal matrix of variances only. Lastly, the regression kriging model is obtained when both the multivariate linear component and the spatially autocorrelated variance-covariance matrix are implemented. All three models were run on the same platform for improved consistency using JAGS (Plummer, 2003) with the rjags package within $\mathrm{R}$ (R Core Team, 2013), while model comparisons were made using AIC (Akaike, 1973). A Bayesian hierarchical approach was implemented to allow for the simultaneous estimation of both the regression model parameters and the spatial autocorrelation parameters used to characterize the covariance matrix. Diffuse priors were used on the parameters following the recommendations of Gelman (2006) and Gelman et al. (2014). The approach therefore allowed development of a unified method for representing and comparing results from the three different models. Furthermore, it prevented the fitting procedure from incorrectly estimating the coefficients under assumptions of independently and identically distributed error, and subsequently using the results to calculate the variogram parameters that are structuring the variance-covariance relationship thus assuming correlation.

Finally, prediction and localized kriging using the parameters previously estimated by the three different model variations on a common JAGS platform was made through application of the Spatial Analyst tools and Raster Calculator in ArcGIS 10.1 (ESRI, 2011). The use of this platform and this modelling approach is unique in how it simultaneously estimates trend and covariation. 


\section{Results}

\subsection{PyC contents}

Predictions of PyC contents and stocks in the New York State and New England area varied considerably between the different models used to generate these estimates (Table 1). For instance, the Ordinary Kriging model showed PyC contents spanning $10.3 \mathrm{~g} \mathrm{~kg}^{-1}$ with a mean of $11.0 \mathrm{~g} \mathrm{~kg}^{-1}$, whereas the range of PyC was much larger for the Multivariate Linear Regression model (spanning $46.8 \mathrm{~g} \mathrm{~kg}^{-1}$; mean $25.8 \mathrm{~g} \mathrm{~kg}^{-1}$ ) and the Bayesian Regression Kriging model (spanning $46.7 \mathrm{~g} \mathrm{~kg}^{-1}$; mean $26.1 \mathrm{~g} \mathrm{~kg}^{-1}$ ), respectively. In terms of spatial distribution (Fig. 2), all three models assessed PyC contents between 8.0 and $11.0 \mathrm{~g} \mathrm{~kg}^{-1}$ to cover more than half of the New York State and New England area (Ordinary Kriging: 54.3\%; Multivariate Linear Regression: 60.6\%; Bayesian Regression Kriging: 62.9\%). Yet, the maximum values of the Ordinary Kriging model (13.0-16.1 $\mathrm{g} \mathrm{kg}^{-1}$ for $4.5 \%$ of the total area) diverged considerably from the other two models $\left(22.0-49.2 \mathrm{~g} \mathrm{~kg}^{-1}\right.$ for $0.4 \%$ of the total area; $22.0-49.4 \mathrm{~g} \mathrm{~kg}^{-1}$ for $0.5 \%$ of the total area). These differences became even more pronounced for PyC stocks (Table 1; Fig. 3).

\subsection{Regression analysis with environmental predictors}

Multivariate analysis was applied to a number of different predictor variables of which total soil S, plant tissue lignin and soil drainage (Fig. 4) were found to be the only ones to show a statistically significant relationship $(\mathrm{P}<0.01)$. However, in the context of our study we found topographic variables such as slope gradient $(P=0.197)$ and aspect $(P=0.238)$, climate factors such as mean annual temperature $(P=0.470)$ and mean annual precipitation $(P=0.572)$ as well as combined silt and clay content $(P=0.475)$ not to be statistically significant. 


\subsection{PyC mapping using three different models}

The two models that included linear predictors (Multivariate Linear Regression: Bayesian Regression Kriging) performed better than the geostatistical model based on PyC observations alone (Ordinary Kriging) as seen from their AIC (Table 2). While the parameter estimates associated with the spatial autocorrelation component all significantly differed from zero, when comparisons among models are made using AIC we found that the two regression-based models do not appreciably differ from one another (delta AIC 3). This indicates that the spatial correlation between observations is low enough to not have had much practical influence on the predictions. Table 2 and Figs. 5 and 6 demonstrate the statistical and practical influence of the three included covariates on the spatial prediction of PyC. The linear trends and 95\% Bayesian credible intervals shown in these figures represent the results from the application of the Bayesian Regression Kriging model. The comparable Multivariate Linear Regression results are so similar to the ones from the Bayesian Regression Kriging model that only one set of figures is shown in Fig. 5. Two leverage points can be seen to influence the relationship between $\mathrm{PyC}$ and S, but the overall positive relationship is still strongly evident (Fig. 5a). The relationship between $\mathrm{PyC}$ and lignin is also positive and significant, however more subtle in its effect (Fig. 5b). Of the drainage conditions, only very poorly drained soils show a statistically significantly higher amount of PyC than the average shown by other soil drainage types (Fig. 5c), representing nearly a doubling in the amount of $\mathrm{PyC}$ present, conditioned on $\mathrm{S}$ and lignin content remaining constant in the system. The interaction of $S$ and drainage was not significant $(P>0.05)$. 


\section{Discussion}

\subsection{PyC accumulation in topsoils}

The spatial variability of PyC in the studied mineral topsoils most likely stems in part from its different sources of both vegetation fires and fossil fuel emissions. Parshall and Foster (2002) have shown through charcoal records in lake sediments of the study region that fire has been a notable environmental factor pre- but even more so post-European settlement. Pre-settlement fire history was mostly driven by climate, vegetation and local physiographic characteristics, with fires less common in areas dominated by hemlock and northern hardwood forest, but at the same time abundant in areas with pitch pine stands on sandy, dry deposits of glacial outwash. European arrival and settlement in New England and New York State brought extensive changes to vegetation structure and composition through the initiation of burning practices (Foster and Zebryk, 1993; Davis et al., 1998; Parshall and Foster, 2002). This brought on a substantial rise of charcoal contents in lake sediments throughout the entire area (Parshall and Foster, 2002) and, presumably, also in parts a localized PyC accumulation in soils. It should be noted that pre-settlement forests were not untouched by humans; for instance, indigenous populations in New England periodically cleared the undergrowth with fire to facilitate hunting and travel (Russell, 1983). In the last century, industrial development led to regionally variable emission and atmospheric transport of fossil fuel-derived C, consequently contributing markedly to PyC deposition in certain areas (Driscoll et al., 2001).

\subsection{PyC relationships with environmental predictors}

As biomass undergoes initial thermal degradation during wildfires, organic molecules release S from primary binding sites. Subsequently, during high 
temperature thermochemical conversion reduced organic $S$ may be retained and bonded to unsaturated C functional groups in the PyC matrix (Knudsen et al., 2004; Cheah et al., 2014). These C-S functional groups may allow for this form of reduced $\mathrm{S}$ bound to $\mathrm{PyC}$ to be preserved in the topsoil for a much longer period of time (Puri and Hazra, 1971) than is possible once organic $\mathrm{S}$ is fully oxidized by pyrolysis to $\mathrm{SO}_{4}$ and subsequently leached from the soil as has been observed elsewhere (Blum et al., 2013; Knudsen et al., 2004). This mechanism might explain the association of PyC and S in our soils.

Moreover, through prevailing winds from west to east, pollutants including soot are emitted in the highly industrialized regions of the Midwest and deposited in the New York State and New England area. It is, therefore, conceivable that atmospheric deposition of $\mathrm{PyC}$ aerosols and $\mathrm{S}$ has led to their joint accumulation in soils of the northeastern United States. Management actions controlling $\mathrm{SO}_{2}$ emissions such as the amendments to the Clean Air Act in the United States resulted in decreases in both emissions and depositions of acidic compounds over the past decades (Driscoll et al., 2001). Because of these measures, along with regular tillage, agricultural soils do not show much change in topsoil S over the past century, although higher levels of subsoil $\mathrm{S}$ suggest that $\mathrm{S}$ deposited by acid rain has migrated deeper by bioturbation or $\mathrm{SO}_{4}$ leaching (Zhuang and McBride, 2013). However, the accumulation effects of decades of atmospheric $\mathrm{S}$ deposition remain evident in forest soils where previously retained $\mathrm{S}$ is only gradually exported (Driscoll et al., 2001). Hence, elevated levels of both $P y C$ and $S$ are found in heavily forested regions such as the Adirondacks in northern New York State, the Catskills in central New York State and the White Mountains in New Hampshire and western Maine (Figs. 2 and 4). Due to large leaf and needle surfaces, forests amplify the impact of 
dry and wet deposition. Pollutants are intercepted and filtered from both air and precipitation before they enter the soil through canopy drip or stemflow. Thus, input loads in forests can exceed deposition on open surfaces by a considerable amount (Blümel, 1986).

It remains a question, however, whether fossil-fuel or vegetation-fire derived PyC and S input dominate the soil contents, given that on the one hand $S$ contents are greater in fossil fuels than biomass (Cordero et al., 2004), whereas on the other hand only $25-30 \%$ of PyC originates from fossil fuels on a national or global level compared to PyC from vegetation fires (Van Der Werf et al., 2010). Additionally, fossil fuel PyC consists mostly of soot and therefore travels large distances (Duffin et al., 2008; Jurado et al., 2008), whereas PyC from vegetation fires encompasses a continuum from charcoal to soot (Preston and Schmidt, 2006) with larger particle sizes making up the vast majority (Kuhlbusch et al., 1996; Saiz et al., 2014). Therefore, most PyC from vegetation fires initially remains close to the site of production (Bird et al., 2015) but is subsequently susceptible to erosion and illuviation (Rumpel et al., 2006; Major et al., 2010; Guereña et al., 2015).

As the influence of fire on individual plant species varies greatly (Heyerdahl et al., 2001), not only the quantity but also the nature of the burnt biomass affects the amount of PyC being produced. Plants with high lignin content produce particularly high proportions of aromatic products during fire and yield more PyC than is obtained from cellulose (Knicker, 2007). Furthermore, thermal degradation of lignin-rich plant material produces less tar, lowering the flammability and thereby favouring subsequent pyrolysis over combustion (Browne, 1958). Conversely, biomass that is low in lignin has higher combustion intensity and therefore yields less PyC compared to lignin-rich biomass when fuel loads are similar (Czimczik et al., 2003; Forbes et 
al., 2006), explaining our results that higher soil PyC contents were observed where the vegetation had greater proportions of lignin.

Soil drainage proves to be a significant factor in $\mathrm{PyC}$ accumulation in soils. In our case, very poorly drained soils show a statistically significantly higher amount of PyC (Figs. 2b, 2c and 4c), which can be explained by abiotic oxidation and biotic mineralization being reduced due to waterlogged conditions (Nguyen and Lehmann, 2009). Additionally, wetter conditions might decrease PyC combustion by subsequent burning events, furthering its accumulation (Glaser and Amelung, 2003).

Questions often arise as to why one study might find key predictors of change, such as topographic characteristics or climate, to be statistically significant in defining a modelled response, while another study may not. The answer lies in part in understanding the influence that the observed range of each predictor will have on the calculation of the significance metrics. If the range of the predictor is so narrow as not to create enough contrast to encumber a change in a response variable, such as PyC, then the predictor variable will not appear to be statistically significant. The predictor may actually be an important driver of processes guiding levels of the response, but if the predictor itself does not vary substantially over the region being assessed, then this importance will go unnoticed. In our case, over $80 \%$ of the observations on slope gradient were between 0 and 10 units. Similarly, the combined silt and clay observations mostly aggregated in the 30 s or in the high 60 s to low 70 s percent range. This is most likely insufficient to detect change. Hence, while predictors like slope gradient, texture or MAT, as suggested by other studies (Paroissien et al., 2012), might have been relevant to the overall processes involved in production and deposition of $\mathrm{PyC}$, we were not able to discern a statistically significant effect because of the low contrast in the range of these potential 
predictors for our study region. The predictor variables were directly obtained from regional data archives, and thus represent the actual range of the data over this region. Therefore, the lack of a statistically significant effect of a particular predictor reflects more its predictive influence on the studied regional scale rather than what might be occurring locally. In addition, analyses of other regions or at a larger scale may identify different predictors.

\subsection{PyC mapping using three different models}

Including auxiliary information of environmental variables improves the resolution of predictions over an area (McBratney et al., 2003). The challenge with using auxiliary information is retrieving these data and accounting for potential autocorrelation in the residuals of any linear regression that is applied. In this paper, we used a Bayesian framework that allowed us to simultaneously calculate the regression parameters and the spatial autocorrelation variogram parameters. This computational approach avoids inappropriately weighting the estimates by failing to account for spatial autocorrelation in the data, and obviates increasing sample spacing for sake of better predictions. We found that the USGS field sites were located far enough apart so that any spatial relationship that might exist on a local scale did not appear to influence the linear fits (Fig. 6). However, such relationships might become more important when data are clustered or characterizations of local dynamics are of greater interest. We used kriged estimates of soil S, plant lignin and soil drainage to establish the input covariates for spatial prediction. These covariates were treated as known, and although they are likely to contain some uncertainties, we disregarded that level of variation in this work for practical (as uncertainty estimates were not available from the source data) and computational reasons. 
However, a Bayesian framework such as the one we developed for the purpose of this paper could be used hierarchically to include this variation as well, if variances were properly characterized in the source data.

Assuming the auxiliary information input is fairly accurate we can visualize the higher level of resolution that this provides in the mapped predictions. The strong relationship between $\mathrm{PyC}$ and S was clearly evident. High concentrations of predicted PyC in southern Maine ( 46.6 $\mathrm{g} \mathrm{kg}^{-1}$ soil) coincides with high levels of $S$ $\left(\sim 4.9 \mathrm{~g} \mathrm{~kg}^{-1}\right.$ soil) (Figs. 2 and 4). This provides some indication that PyC levels might be higher here than what sample observations alone in this area would indicate. A second example is the Adirondacks region where a single global high is evident in the Ordinary Kriging predictions, but more detail in the predictions can be seen once auxiliary information is included.

Estimates for the entire dataset confirmed that considering auxiliary information made a difference to the estimates of the spatial distribution of PyC. Mean estimates that took auxiliary information into account were more than two times greater than mean estimates that did not (Table 1). Furthermore, the variation as exemplified by the range and the standard deviation of the predictions more accurately reflected the span of $\mathrm{PyC}$ over the region, all based on regressions with the measured point estimates (Supplementary Fig. S1). The Bayesian hierarchical model that was used to estimate the regression relationships while simultaneously accounting for the spatial autocorrelation better accounts for the multivariate and nonlinear associations in the system when making landscape scale predictions and we therefore encourage the use of these more statistically sophisticated approaches in the future. Furthermore, uncertainty in database-derived metrics could be readily incorporated through the Bayesian hierarchical approach. 


\section{Conclusions}

In summary, PyC contents in mineral topsoils (A horizon, after removal of any organic horizons) of the northeastern United States were closely associated with factors controlling its production (plant lignin), formation process (total soil S) and accumulation or movement (soil drainage). These environmental covariates proved useful for parameterizing spatial models of $\mathrm{PyC}$ distribution with otherwise limited direct observations of only one site per $1600 \mathrm{~km}^{2}$. Therefore, these models performed significantly better than a model based on $\mathrm{PyC}$ point observations alone. Global biogeochemical $\mathrm{C}$ budgets rely on accurate assessments of $\mathrm{C}$ reserves in soils, and its cycles on understanding SOC vulnerability to mineralization. To achieve this, measurements across a continental scale will be helpful in establishing purposive relationships to critical covariates in order to better enhance estimates under what will always be limitations in direct soil sampling. More appropriate statistical modelling techniques as well as taking advantage of spatially covarying sets of observations might also help improve predictions. It is important to find enough contrast in the set of the environmental covariates for them to be statistically significant in making predictions on the response variable PyC. Future research may also benefit from identifying the possibly varied sources of $\mathrm{PyC}$ and $\mathrm{S}$ using isotope techniques. Moreover, understanding the speciation of $S$ could aid in furthering our understanding of biogeochemical mechanisms linking $\mathrm{S}$ to $\mathrm{PyC}$ in soils. Future spatial analyses of other regions or different spatial scales should use the current Bayesian hierarchical approach of spatial modelling, and examine the entire set of possible predictors even if they were not significantly related to PyC in our study. 


\section{Acknowledgements}

This study was funded by NASA-USDA award No. 2008-35615-18961 and the

Department of Soil and Crop Sciences at Cornell University. The authors thank Leonie R. Spouncer and Bruce Hawke for help with the MIR analyses and data processing. Thanks are also due to Murray McBride, Akio Enders and Bernhard Jakob for their continued advice and support in performing this study.

\section{References}

Abideen, Z., Ansari, R., Khan, M.A., 2011. Halophytes: Potential source of lignocellulosic biomass for ethanol production. Biomass Bioenerg. 35, 1818-1822.

Akaike, H., 1973. Information theory and an extension of the maximum likelihood principle. in: Petrov, B.N., Csáki, F. (Eds.), 2nd International Symposium on Information Theory. Akadémiai Kiadó, Tshakadsor, Armenia, USSR, pp. 267281.

Ansley, R.J., Boutton, T.W., Skjemstad, J.O., 2006. Soil organic carbon and black carbon storage and dynamics under different fire regimes in temperate mixedgrass savanna. Global Biogeochem. Cy. 20, 1-11.

Ballabio, C., Panagos, P., Monatanarella, L., 2016. Mapping topsoil physical properties at European scale using the LUCAS database. Geoderma 261, 110123.

Baldock, J.A., Sanderman, J., Macdonald, L. M., Puccini, A., Hawke, B., Szarvas, S., McGowan, J., 2013a. Quantifying the allocation of soil organic carbon to biologically significant fractions. Aust. J. Soil Res. 51, 561-576.

Baldock, J.A., Hawke, B., Sanderman, J., Macdonald, L.M., 2013b. Predicting contents of soil carbon and its component fractions from diffuse reflectance mid-infrared spectra. Aust. J. Soil Res. 51, 577-595.

Beyer, H.L., 2004. Hawth's Analysis Tools for ArcGIS. http://www.spatialecology.com/htools

Bird, M.I., Wynn, J.G., Saiz, G., Wurster, C.M., McBeath, A., 2015. The pyrogenic carbon cycle. Ann. Rev. Earth Planet. Sci. 43, 273-298.

Blümel, W.D., 1986. Waldbodenversauerung. Gefährdung eines ökologischen Puffers und Reglers. Geogr. Rundschau 38 (6), 312-320. 
Blümel, W.D., 2009. Natural Climatic Variations in the Holocene: Past Impacts on Cultural History, Human Welfare and Crisis. in: Brauch, H.G. et al. (Eds.), Facing Global Environmental Change. Environmental Human, Energy, Food, Health and Water Security Concepts. Springer Verlag, Berlin, Germany, pp. 103-116.

Blum, S.C., Lehmann, J., Solomon, D., Caires, E.F., Alleoni, L.R.F., 2013. Sulfur forms in organic substrates affecting $S$ mineralization in soil. Geoderma 200, 156-164.

Brauns, F.E., Brauns, D.A., 1960. The chemistry of lignin. Supplement volume, covering the literature for the years 1949-1958, Academic Press, New York, NY.

Bray, S.R., Kitajima, K., Mack, M.C., 2012. Temporal dynamics of microbial communities on decomposing leaf litter of 10 plant species in relation to decomposition rate. Soil Biol. Biochem. 49, 30-37.

Briggs, P.H., 2002. The determination of forty elements in geological and botanical samples by inductively coupled plasma-atomic emission spectrometry, chap. G. in: Taggart, J.E., Jr. (Ed.), Analytical methods for chemical analysis of geologic and other materials, U.S. Geological Survey: U.S. Geological Survey Open-File Report 02-223, 18 pp.

Brodowski, S., Amelung, W., Haumaier, L., Abetz, C., Zech W., 2005. Morphological and chemical properties of black carbon in physical soil fractions as revealed by scanning electron microscopy and energy-dispersive X-ray spectroscopy. Geoderma, 128, 116-129.

Browne, F.L., 1958. Theories on the combustion of wood and its control. Forest Products Laboratory Report No. 2136. U.S. Department of Agriculture, Madison, WI, 69 pp.

Butkuté, B., Lemežiené, N., Cesevičiené, J., Liatukas, Ž., Dabkevičiené G., 2013. Carbohydrate and lignin partitioning in switchgrass (Panicum virgatum L.) biomass as a bioenergy feedstock. Zemdirbyste-Agriculture 100 (3), 251-260.

Cheah, S., Malone S.C., Feik, C.J., 2014. Speciation of sulfur in biochar from pyrolysis and gasification of oak and corn stover. Environ. Sci. Tech. 48, 84748480.

Conn, C.E., 1994. The role of nitrogen availability, hydroperiod and litter quality in root decomposition along a barrier island chronosequence. PhD thesis. Dep. of Ecol. Sci., Old Dominion Univ., Norfolk, VA, 126 pp.

Cook, C.W., Harris L.E., 1952. Nutritive value of cheatgrass and crested wheatgrass on spring ranges in Utah. J. Range Manage. 5 (5), 331-338. 
Cordero, T., Rodríguez-Mirasol, J., Pastrana J., Rodríguez J.J., 2004. Improved solid fuels from co-pyrolysis of a high-sulphur content coal and different lignocellulosic wastes. Fuel 83, 1585-1590.

Corker, T.C. Jr., Boyer, W.D., 1975. Regenerating longleaf pine naturally. Res. Pap. SO-105. U.S. Department of Agriculture, Forest Service, Southern Forest Experiment Station. New Orleans, LA. 26p.

Czimczik, C.I., Preston, C.M., Schmidt, M.W.I., Schulze E.D., 2003. How surface fire in Siberian Scots pine forests affects soil organic carbon in the forest floor: stocks, molecular structure, and conversion to black carbon (charcoal). Global Biogeochem. Cycles 17, 1020-1034.

Davidson, E.A., Janssens, I.A., 2006. Temperature sensitivity of soil carbon decomposition and feedbacks to climate change. Nature 440, 165-173.

Davis, M.B., Calcote, R.R., Sugita, S.S., Takahara H., 1998. Patchy invasion and the origin of a hemlock-hardwoods forest mosaic. Ecology 79, 2641-2659.

Driscoll, C.T., Lawrence, G.B., Bulger, A.J., Butler, T.J., Cronan, C.S., Eagar, C., Lambert, K.F., Likens, G.E., Stoddard, J.L., Weathers K.C., 2001. Acidic deposition in the Northeastern United States: sources and inputs, ecosystem effects, and management strategies. BioScience 51 (3), 180-198.

Duffin, K.I., Gillson, L., Willis, K.J., 2008. Testing the sensitivity of charcoal as an indicator of fire events in savanna environments: quantitative predictions of fire proximity, area and intensity. Holocene 18, 279-291.

ESRI, 2009. ArcGIS Desktop: Release 9.3. Redlands, CA: Environmental Systems Research Institute.

ESRI, 2011. ArcGIS Desktop: Release 10. Redlands, CA: Environmental Systems Research Institute.

Forbes, M.S., Raison R.J., Skjemstad J.O., 2006. Formation, transformation and trans-port of black carbon (charcoal) in terrestrial and aquatic ecosystems. Sci. Total Environ. 370, 190-206.

Foster, D.R., Zebryk, T.M., 1993. Long-term vegetation dynamics and disturbance history of a Tsuga-dominated forest in New England. Ecology 74, 982-998.

Friedlingstein, P., Cox, P.M., Betts, R.A., von Bopp, L., Bloh, W., Brovki,V., Cadule, P., Doney, S., Eby, M., Fung, I., Bala, G., John, J., Jones, C., Joos, F., Kato, T., Kawamiya, M., Knorr, W., Lindsay, K., Matthews, H.D., Raddatz, T., Rayner, P.J., Reick, C., Roeckner, E., Schnitzler, K.G., Schnur, R., Strassmann, K., Weaver, A.J., Yoshikawa, C.,Zeng N., 2006. Climate carbon cycle feed-back analysis: results from the C4MIP model intercomparison. J. Clim. 19 (14), 3337-3353. 
Fukushima, R.S., Hatfield, R.D., 2004. Comparison of the acetyl bromide spectrophotometric method with other analytical lignin methods for determining lignin concentration in forage samples. J. Agric. Food Chem. 52, 3713-3720.

Gelman, A. 2006. Prior distributions for variance parameters in hierarchical models. Bayesian Analysis, 1: 515-533.

Gelman, A., Carlin, J.B., Stern, H.S., Dunson, D.B., Vehtari A., Rubin, D.B., 2014. Bayesian Data Analysis (3rd edn.), Chapman and Hall/CRC Press, Boca Raton. xiv, $661 \mathrm{pp}$.

Glaser, B., Amelung, W., 2003. Pyrogenic carbon in native grassland soils along a climosequence in North America. Global Biogeochem. Cy. 17 (2), 1064.

Goudie, A.S., 2001. The nature of the environment. Wiley Blackwell, Oxford, UK.

Guereña, D.T., Lehmann, J., Walter, T., Enders, A., Neufeldt, H., Odiwour, H., Biwott, H., Recha, J., Shephard, K., Barrios, E., Wurster, C., 2015. Terrestrial pyrogenic carbon export to fluvial ecosystems: Lessons learned from the White Nile watershed of East Africa. Global Biogeochem. Cy. 29 (10), GB005095.

Hengl, T., Heuvelink, G.B., Kempen, B., Leenaars, J.G., Walsh, M.G., Shepherd, K.D., Sila, A., MacMillan, R.A., de Jesus, J.M., Tamene, L., Tondoh, J.E., 2015. Mapping soil properties of Africa at $250 \mathrm{~m}$ resolution: Random forests significantly improve current predictions. PloS One 10, e0125814.

Heyerdahl, E.K., Burbacker, L.B., Agee, J.K., 2001. Annual and decadal climate forcing of historical fire regimes in the interior Pacific Northwest, USA. Holocene 12 (5), 597-604.

IPCC, 2014. Climate Change 2014: Synthesis Report. Contribution of Working Groups I, II and III to the Fifth Assessment Report of the Intergovernmental Panel on Climate Change [Core Writing Team, R.K. Pachauri and L.A. Meyer (Eds.)]. IPCC, Geneva, Switzerland, 151 pp.

Janik, L.J., Skjemstad, J.O., Shepherd, K.D., Spouncer, L.R., 2007. The prediction of soil carbon fractions using mid-infrared-partial least square analysis. Aust. J. Soil Res. 45, 73-81.

Jurado, E., Dachs, J., Duarte, C.M., Simó, R., 2008. Atmospheric deposition of organic and black carbon to the global oceans. Atmos. Environ. 42, 7931-39.

Klason, P., 1908. Chemical composition of deal (Fir wood). Ark. Kemi. Mineral. Geol. 3, 1-10.

Kleber, M., Sollins, P., Sutton, R., 2007. A conceptual model of organo-mineral interactions in soils: self-assembly of organic molecular fragments into zonal structures on mineral surfaces. Biogeochemistry 85, 9-24. 
Knicker, H., 2007. How does fire affect the nature and stability of soil organic nitrogen and carbon? A review. Biogeochemistry 85, 91-118.

Knudsen, J.N., Jensen, P.A., Lin, W., Frandsen, F.J., Dam-Johansen, K., 2004. Sulfur transformation during thermal conversion of herbaceous biomass. Energy Fuels 18, 810-819.

Kuhlbusch T.A.J., Andreae, M.O., Cachier, H., Goldammer, J.G., Lacaux, J.P., 1996. Black carbon formation by savanna fires: measurements and implications for the global carbon cycle. J. Geophys. Res. 101(D19), 23651-23665.

Kuhlbusch, T.A.J., 1998. Black carbon and the carbon cycle. Science 280, 19031904.

Lamoot, I., 2004. Foraging behaviour and habitat use of large herbivores in a coastal dune landscape. PhD thesis. Dep. of Biol., Ghent Univ., Ghent, Belgium, 174 pp.

Laursen, K.R., 2004. The effects of nutrient enrichment on the decomposition of belowground organic matter in Sagittaria lancifolia - dominated oligohaline marsh. M.S. thesis. Dep. of Oceanogr. and Coast. Sci., Lousiana State Univ., Baton Rouge, LA, 80 pp.

Lehmann, J., Skjemstad, J., Sohi, S., Carter, J., Barson, M., Falloon, P., Coleman, K., Woodbury, P., Krull, E., 2008. Australian climate-carbon cycle feedback reduced by soil black carbon. Nature Geosci. 1, 832-835.

Lehmann, J., Abiven, S., Kleber, M., Pan, G., Singh, B.P., Sohi, S.P., Zimmerman, A.R., 2015. Persistence of biochar in soil. in: J. Lehmann and S. Joseph (Eds.), Biochar for environmental management: science, technology and implementation. Routledge, Taylor \& Francis Group, New York, NY, pp. 235282.

Major, J., Lehmann, J., Rondon, M., Goodale, C., 2010. Fate of soil-applied black carbon: downward migration, leaching and soil respiration. Glob. Change Biol. 16, 1366-1379.

McBratney, A. B., Santos, M. M., Minasny, B. 2003. On digital soil mapping. Geoderma 117, 3-52.

Murage, E.W., Voroney P., Beyaert, R.P., 2007. Turnover of carbon in the free light fraction with and without charcoal as determined using the $13 \mathrm{C}$ natural abundance method. Geoderma 138, 133-143.

The National Map LANDFIRE: LANDFIRE National Existing Vegetation Type layer, 2006. U.S. Department of Interior, Geological Survey. [Online]. Available: http://gisdata.usgs.net/website/landfire/ [2007, February 8].

Nguyen, B.T., Lehmann, J., 2009. Black carbon decomposition under varying water regimes. Org. Geochem. 40, 846-853. 
Ohlson M., Tryterud E., 2000. Interpretation of the charcoal record in forest soils: Forest fires and their production and deposition of macroscopic charcoal. Holocene 10, 519-525.

Ostrofsky, M.L., 1997. Relationship between chemical characteristics of autumnshed leaves and aquatic processing rates. J. N. Am. Benthol. Soc. 16 (4), 750759.

Pan, Y., Birdsey, R.A., Fang, J., Houghton, R., Kauppi, P.E., Kurz, W.A., Phillips, O.L., Shvidenko, A., Lewis, S.L., Canadell, J.G., Ciais, P., 2011. A large and persistent carbon sink in the world's forests. Science 333, 988-993.

Park, Y.C., Kim, J.S., 2012. Comparison of various alkaline pretreatment methods of lignocellulosic biomass. Energy 47, 31-35.

Paroissien, J.-B., Orton, T.G., Saby, N.P.A., Martin, M.P., Jolivet, C.C., Ratie, C., Caria, G., Arrouays, D., 2012. Mapping black carbon content in topsoils of central France. Soil Use Manage. 28 (4), 488-496.

Parshall, T., Foster D.R., 2002. Fire on the New England landscape: regional and temporal variation, cultural and environmental controls. J. Biogeogr. 29, 13051317.

Pettersen, R.C., 1984. The Chemical Composition of Wood. in: Rowell, R.M. (Ed.), The Chemistry of Solid Wood. American Chemical Society, Washington, D.C., pp. 57-126.

Pickering, K., 2008. Properties and performance of natural fibre composites, Woodhead Publishing, Cambridge, UK.

Plummer, M., 2003. JAGS: A program for analysis of Bayesian graphical models using Gibbs sampling; Proceedings of the 3rd International Workshop on Distributed Statistical Computing; Vienna, Austria.

Preston, C.M., Schmidt, M.W.I., 2006. Black (pyrogenic) carbon: a synthesis of current knowledge and uncertainties with special consideration of boreal regions. Biogeosciences 3, 397-420.

Puri, B.R., Hazra R.S., 1971. Carbon-sulphur surface complexes on charcoal. Carbon 9, 123-134.

R Core Team, 2013. R: A language and environment for statistical computing. $R$ Foundation for Statistical Computing, Vienna, Austria. ISBN 3-900051-07-0, URL http://www.R-project.org/.

Reisser, M., Purves, R., Schmidt, M.W., Abiven, S., 2016. Pyrogenic Carbon in soils: a literature-based inventory and a global estimation of its content in soil organic carbon and stocks. Front. Earth Sci. 4, 80. 
Rowell, R.M., 2005. Handbook of wood chemistry and wood composites, Taylor \& Francis, Boca Raton, FL.

Rumpel, C., Chaplot, V., Planchon, O., Bernadou, J., Valentin, C., Mariotti A., 2006. Preferential erosion of black carbon on steep slopes with slash and burn agriculture. Catena 65, 30-40.

Russell, E.W.B., 1983. Indian-set fires in the forests of the Northeastern United States. Ecology. 64 (1), 78-88.

Saiz, G., Wynn, J.G., Wurster, C.M., Goodrick, I., Nelson, P.N., Bird, M.I., 2014. Pyrogenic carbon from tropical savanna burning: production and stable isotope composition. Biogeosci. Disc. 11, 15149-83.

Santín, C., Doerr, S.H., Kane, E.S., Masiello, C.A., Ohlson, M., Rosa, J.M., Preston, C.M., Dittmar, T., 2016. Towards a global assessment of pyrogenic carbon from vegetation fires. Global Change Biol. 22, 76-91.

Schimel, D.S., House, J.I., Hibbard, K.A., Bousquet, P., Ciais, P., Peylin, P., Braswell, B.H., Apps, M.J., Baker, D., Bondeau, A., Canadell, J., 2001. Recent patterns and mechanisms of carbon exchange by terrestrial ecosystems. Nature 414, 169-172.

Schmidt, M.W.I., Noack, A.G., 2000. Black carbon in soils and sediments: Analysis, distribution, implications, and current challenges. Global Biogeochemical Cycles 14: 777-793.

Schmidt, M.W.I., Torn, M.S., Abiven, S., Dittmar, T., Guggenberger, G., Janssens, I.A., Kleber, M., Kögel-Knabner, I., Lehmann, J., Manning, D.A.C., Nannipieri, P., Rasse, D.P., Weiner, S., Trumbore S.E., 2011. Persistence of soil organic matter as an ecosystem property. Nature $478,49-56$.

Severson, K.E., Ursek D.W., 1988. Influence of Ponderosa Pine overstory on forage quality in the Black Hills, South Dakota. Great Basin Nat. 48 (1), 78-82.

Shaoda, L., Xinghui, X., Yawei, Y., Ran, W., Ting, L., Shangwei, Z., 2011. Black carbon $(B C)$ in urban and surrounding rural soils of Beijing, China: Spatial distribution and relationship with polycyclic aromatic hydrocarbons (PAHs). Chemosphere 82, 223-228.

Sharpe, D.M., Cromack Jr., K., Johnson, W.C., Ausmus, B.S., 1980. A regional approach to litter dynamics in Southern Appalachian forests. Can. J. For. Res. $10,395-404$.

Singh, N., Abiven, S., Torn, M.S., Schmidt, M.W.I., 2012. Fire-derived organic carbon in soil turns over on a centennial scale. Biogeosciences 9, 2847-2857.

Skjemstad, J.O., Reicosky D.C., Wilts A.R., McGowen J.A., 2002. Charcoal carbon in U.S. agricultural soils. Soil Sci. Soc. Am. J. 66, 1249-1255. 
Smith, L.M., Kadlec, J.A., 1984. Effects of prescribed burning on nutritive quality of marsh plants in Utah. J. Wildl. Manage. 48 (1), 285-288.

Smith, D.B., Cannon, W.F., Woodruff, L.G., Rivera, F.M., Rencz, A.N., Garrett, R.G., 2012. History and progress of the North American Soil Geochemical Landscapes Project, 2001-2010, 2012. Earth Science Frontiers 19 (3), 19-32.

Smith, D.B., Cannon, W.F., Woodruff, L.G., Solano, F., Kilburn, J.E., Fey, D.L., 2013. Geochemical and mineralogical data for soils of the conterminous United States: U.S. Geological Survey Data Series 801, 19 p., http://pubs.usgs.gov/ds/801/.

Smith, D.B., Cannon, W.F., Woodruff, L.G., Solano, F., Ellefsen, K.J., 2014. Geochemical and mineralogical maps for soils of the conterminous United States. U.S. Geological Survey Open-File Report 2014-1082, 386 p., http://pubs.usgs.gov/of/2014/1082/.

Soil Survey Staff, Natural Resources Conservation Service. United States Department of Agriculture, 2006. U.S. General Soil Map (STATSGO2). [Online]. Available: http://soildatamart.nrcs.usda.gov

Spokas, K.A., 2010. Review of the stability of biochar in soils: predictability of O:C molar ratios. Carbon Manage. 1, 289-303.

Stevens, D.L., Jr., Olsen, A.R., 2004. Spatially balanced sampling of natural resources. J. Am. Statist. Assoc. 99 (465), 262-278.

Sultan, J.I., Rahim, I.U., Yaqoob, M., Mustafa, M.I., Nawaz, H., Akhtar, P., 2009. Nutritional evaluation of herbs as fodder source for ruminants. Pak. J. Bot. 41 (6), 2765-2776.

Tian, H., Lu, C., Yang, J., Banger, K., Huntzinger, D.N., Schwalm, C.R., Michalak, A.M., Cook, R., Ciais, P., Hayes, D., Huang, M., 2015. Global patterns and controls of soil organic carbon dynamics as simulated by multiple terrestrial biosphere models: Current status and future directions. Global Biogeochem. Сy. 29, 775-792.

Van Der Werf G.R., Randerson J.T., Giglio L, Collatz, G. J., Mu, M., Kasibhatla, P.S., Morton, D.C., DeFries, R.S., Jin, Y., van Leeuwen, T.T., 2010. Global fire emissions and the contribution of deforestation, savanna, forest, agricultural, and peat fires (1997-2009). Atmos. Chem. Phys. 10, 11707-11735.

Van Niekerk, W.A., Sparks, C.F., Rethman, N.F.G., Coertze R.J., 2004. Qualitative characteristics of some Atriplex species and Cassia sturtii at two sites in South Africa. S. Afr. J. Anim. Sci. 34 (Supplement 1), 108-110.

Wainio, W.W., Forbes, E.B., 1941. The chemical composition of forest fruits and nuts from Pennsylvania. J. Agric. Res. 62 (10), 627-635. 
Wang, J., Xiong, Z., Kuzyakov, Y., 2015. Biochar stability in soil: meta-analysis of decomposition and priming effects. GCB Bioenergy 8 (3), 512-523.

Wenzl, H.F.J., 1970. The chemical technology of wood. Academic Press, New York, NY.

Wilson, J.O., 1985. Decomposition of $\left[{ }^{14} \mathrm{C}\right]$ lignocelluloses of Spartina alterniflora and a comparison with field Experiments. Appl. Environ. Microb. 49 (3), 478-484.

Woodward, S.L., 2003. Biomes of Earth: Terrestrial, Aquatic, and Human-dominated. Greenwood Press, Menlo Park, CA.

Zhuang, P., McBride, M.B., 2013. Changes during a century in trace element and macronutrient concentrations of an agricultural soil. Soil Sci. 178 (3), 105-108.

Zimmerman, A.R., 2010. Abiotic and microbial oxidation of laboratory-produced black carbon (biochar). Environ. Sci. Tech. 44, 1295-1301. 
Table 1. Global estimates of PyC contents $\left[\mathrm{g} \mathrm{kg}^{-1}\right.$ soil] and in parentheses PyC stocks $^{\mathrm{a}}\left[\mathrm{Gg} \mathrm{km}^{-2}\right]$.

\begin{tabular}{lcccc}
\hline \multicolumn{1}{c}{ Model } & Mean & $\begin{array}{c}\text { Standard } \\
\text { Deviation }\end{array}$ & Minimum & Maximum \\
\hline Ordinary Kriging & $\begin{array}{l}11.00 \\
(0.84)\end{array}$ & $\begin{array}{c}2.98 \\
(0.29)\end{array}$ & $\begin{array}{c}5.80 \\
(0.00)\end{array}$ & 16.10 \\
& & & & $(1.56)$ \\
Multivariate & 25.76 & 13.48 & 2.42 & 49.20 \\
$\begin{array}{l}\text { Linear } \\
\text { Regression }\end{array}$ & $(12.23)$ & $(7.43)$ & $(0.00)$ & $(40.54)$ \\
$\begin{array}{l}\text { Bayesian } \\
\text { Regression }\end{array}$ & 26.09 & 13.45 & & 2.80 \\
Kriging & $(12.39)$ & $(7.50)$ & $(0.00)$ & 49.49 \\
\hline
\end{tabular}

${ }^{\text {a }}$ Stocks were calculated using the following formula: PyC Stocks $\left[\mathrm{Gg} \mathrm{km}^{-2}\right]=\mathrm{PyC}$ concentration $\left[\mathrm{g} \mathrm{kg}^{-1}\right.$ soil] * Bulk Density $\left[\mathrm{Mg} \mathrm{m}^{-3}{ }^{*}\right.$ Layer Thickness [m] (stocks reported within the precision of the data) 
Table 2. Parameter estimates for three Bayesian models.

\begin{tabular}{|c|c|c|c|c|c|c|}
\hline & \multicolumn{2}{|c|}{ Ordinary Kriging } & \multicolumn{2}{|c|}{$\begin{array}{l}\text { Multivariate Linear } \\
\text { Regression }\end{array}$} & \multicolumn{2}{|c|}{$\begin{array}{c}\text { Bayesian Regression } \\
\text { Kriging }\end{array}$} \\
\hline & Value & SE & Value & SE & Value & SE \\
\hline Intercept & 9.183 & 0.671 & 3.344 & 0.985 & 3.477 & 0.933 \\
\hline Soil sulphur & & & 6.050 & 0.489 & 6.150 & 0.440 \\
\hline Plant lignin & & & 0.008 & 0.003 & 0.007 & 0.003 \\
\hline Soil drainage & & & & & & \\
\hline $\begin{array}{l}\text { Somewhat } \\
\text { excessively } \\
\text { drained }\end{array}$ & & & -0.920 & 1.313 & -0.673 & 1.214 \\
\hline Well drained & & & 1.914 & 0.103 & 0.173 & 0.960 \\
\hline $\begin{array}{l}\text { Moderately well } \\
\text { drained }\end{array}$ & & & 1.622 & 1.261 & 1.662 & 1.115 \\
\hline $\begin{array}{l}\text { Somewhat } \\
\text { poorly drained }\end{array}$ & & & 1.560 & 1.218 & 1.901 & 1.148 \\
\hline Poorly drained & & & 1.825 & 1.158 & 1.661 & 1.089 \\
\hline $\begin{array}{l}\text { Very poorly } \\
\text { drained }\end{array}$ & & & 7.683 & 2.653 & 7.535 & 2.631 \\
\hline Range & 132027 & 26004 & & & 163072 & 26150 \\
\hline PSill & 8.989 & 4.196 & & & 1.616 & 0.990 \\
\hline Tau & 0.044 & 0.007 & 0.084 & 0.011 & 0.094 & 0.012 \\
\hline $\mathrm{AIC}$ & 982.4 & & 842.6 & & 979.2 & \\
\hline
\end{tabular}




\section{Figure Captions}

Fig. 1. Scatterplot outlier vs inlier ratio of PyC measurements $(n=165)$. Both metrics are calculated using the Unscrambler. The outlier ratio is based on Hotellings Tvalue and the inlier ratio is based on Mahalanobis distance. Horizontal and vertical lines at 1.0 are provided for reference.

Fig. 2. PyC content $\left[\mathrm{g} \mathrm{kg}^{-1}\right.$ soil] assessment for New York and New England: a) Ordinary Kriging; b) Multivariate Linear Regression; c) Bayesian Regression Kriging.

Fig. 3. PyC Stocks $\left[\mathrm{Gg} \mathrm{km}^{-2}\right]$ for topsoils in New York and New England: a) Ordinary Kriging; b) Multivariate Linear Regression; c) Bayesian Regression Kriging.

Fig. 4. Environmental predictors used in Multivariate Linear Regression and Bayesian Regression Models: a) Ordinary Kriging of total soil sulphur measurements from 165 field sites; b) Plant tissue lignin contents according to existing vegetation type (The National Map LANDFIRE, 2006); c) Soil drainage classes for topsoil (STATSGO 2.0, 2006). Areas in white represent missing data, principally water bodies and major cities.

Fig.5. (a) Relationship between PyC and total soil sulphur with median line and 95\% Bayesian Credible Interval (BCI) from MCMC. (b) Relationship between PyC and plant tissue lignin with median line and 95\% Bayesian Credible Interval $(\mathrm{BCl})$ from MCMC. (c) Boxplot of soil drainage classes (VPD=very poorly drained, PD=poorly drained, SPD=somewhat poorly drained, MWD=moderately well drained, $\mathrm{WD}=$ well 
drained, SED=somewhat excessively drained, ED=excessively drained) and PyC median and 95\% Bayesian Credible Intervals (BCl) from MCMC.

Fig. 6. Semivariogram (i.e., sill minus covariogram) fit to PyC for Ordinary Kriging and to the simultaneously estimated residuals from the fit to PyC for Bayesian Regression Kriging. Circle size represents the pairwise sample size for spatial correlation between Ordinary Kriging and Bayesian Regression Kriging. 
Fig. 1.

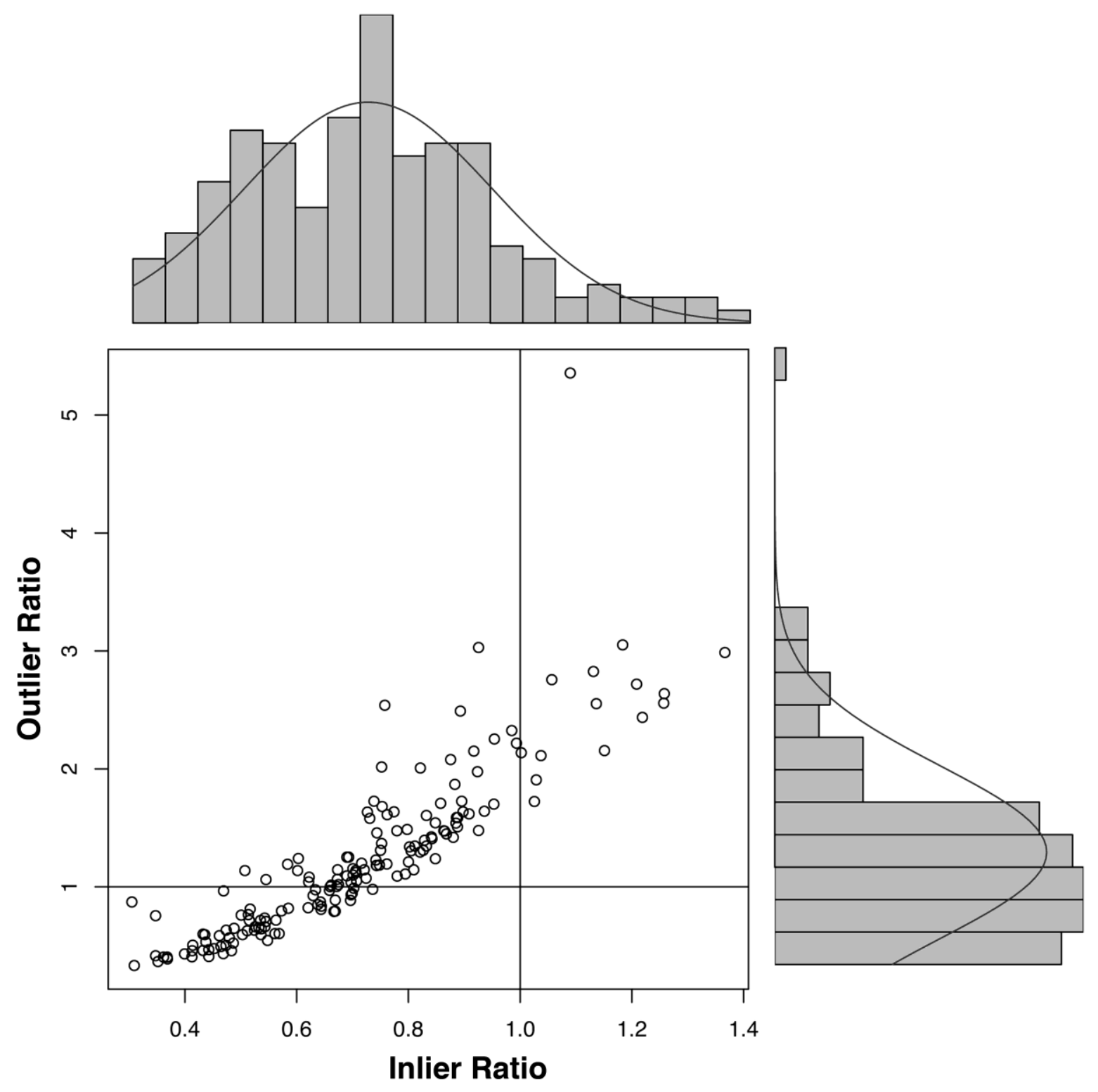


Fig. 2.

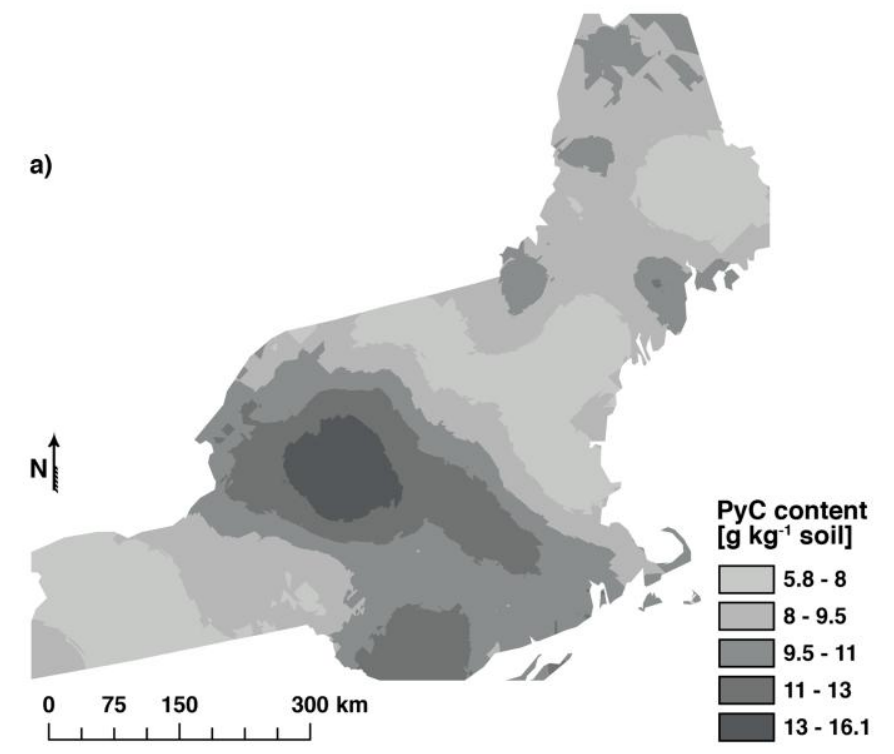

b)

c)

PyC content

[g kg-1 soil]

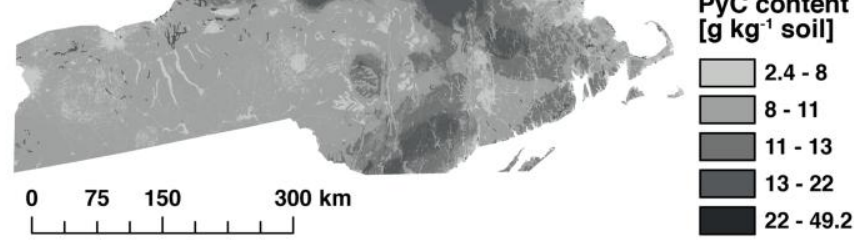

PyC content

[g kg-1 soil]

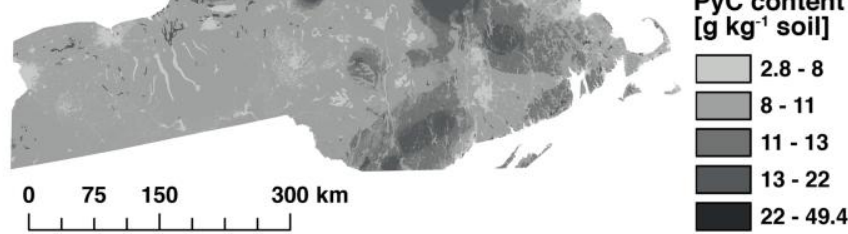


Fig. 3. 
a)

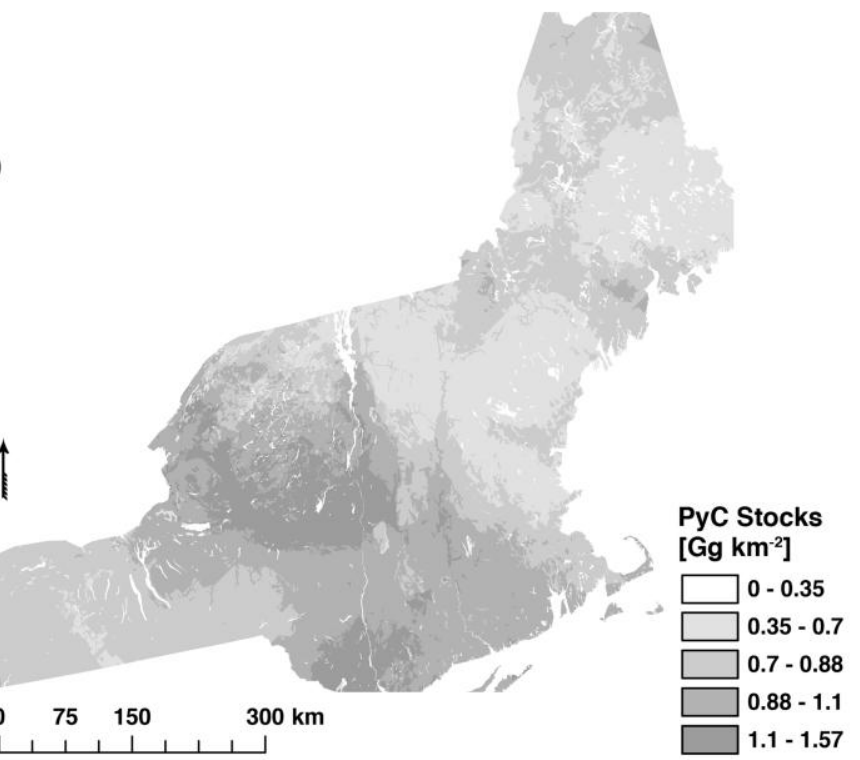

b)

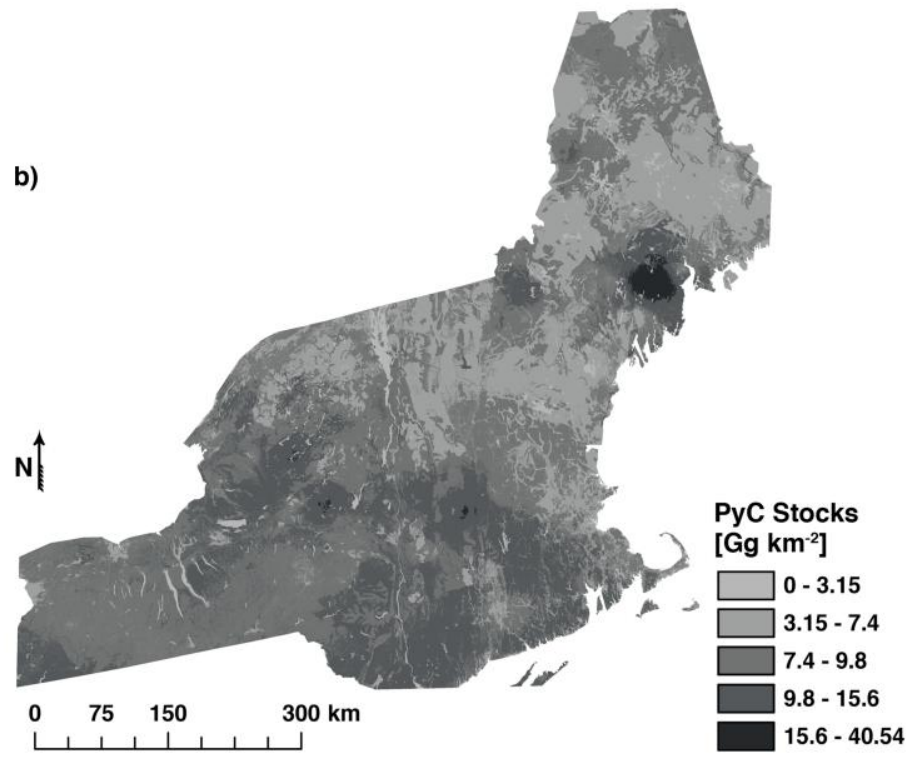

c)

PyC Stocks

[Gg km-2]

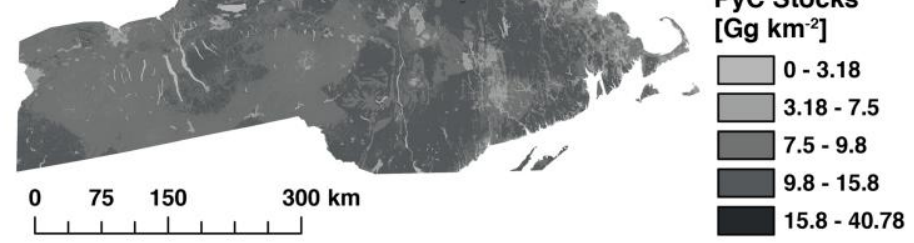


Fig. 4.

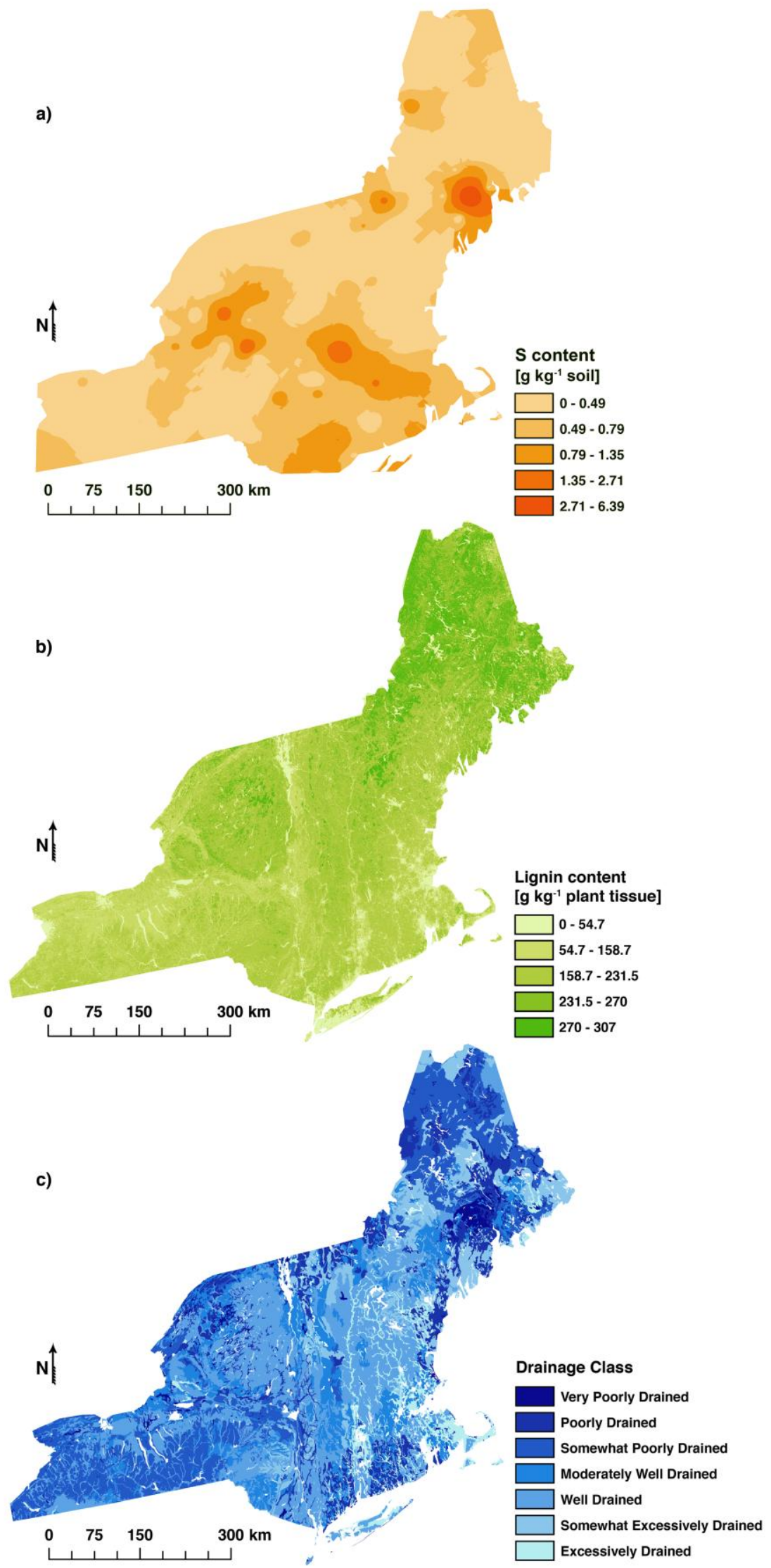


Fig. 5.

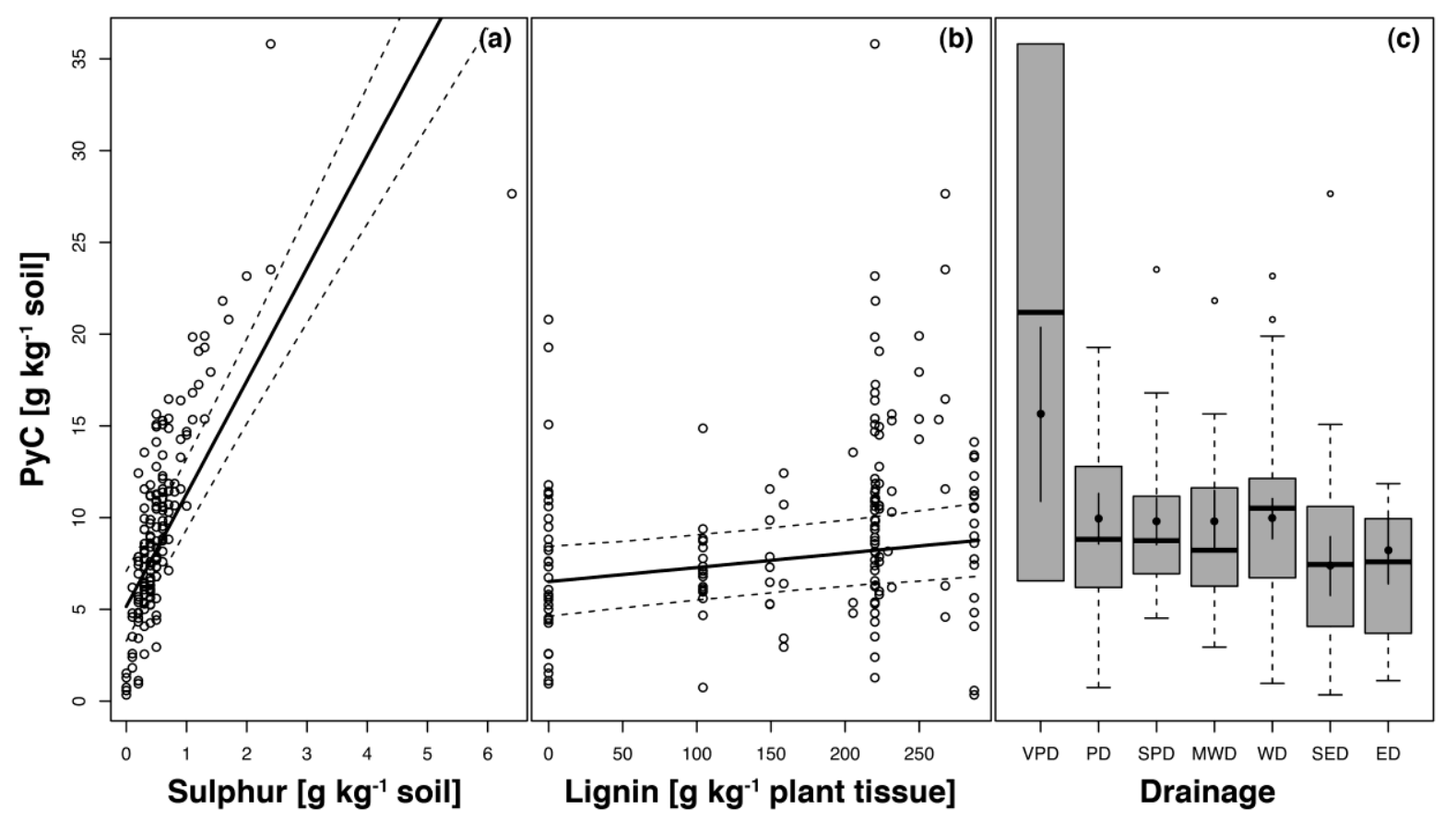


Fig. 6 .

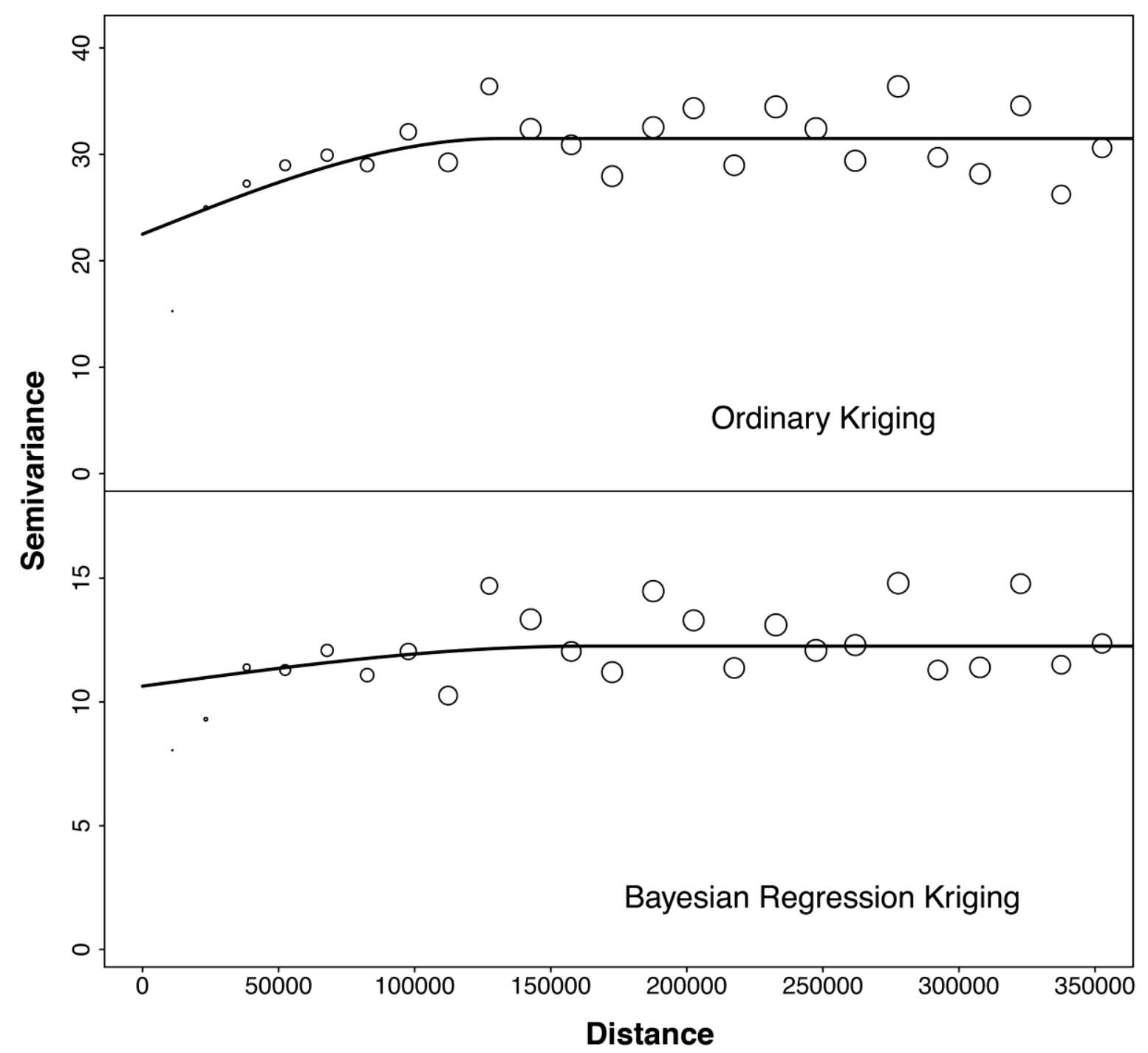

